\title{
Umframávöxtun á íslenskum hlutabréfamarkaði
}

\author{
Ásgeir Jónsson og Stefán B. Gunnlaugsson. ${ }^{1}$
}

\begin{abstract}
Ágrip
Hér er gerð grein fyrir rannsókn á sambandi nokkurra kennitalna fyrirtækja og ávöxtunar íslenskra hlutabréfa. Pær kennitölur sem um ræðir eru V/H-hlutfall, qhlutfall, arðhlutfall, söguleg ávöxtun og fyrirtækjastærð. Rannsóknin nær yfir tímabilið frá janúar 1993 til júní 2003 og er byggð á pví að búa til ný verðbréfasöfn í hverjum mánuði eftir peim kennitölum sem rannsakaðar voru. Ávöxtun verðbréfasafnanna var síðan reiknuð og kannað hvort marktækur munur væri á milli peirra að teknu tilliti til kerfisbundinnar áhættu. Helstu niðurstöður eru pær að hlutabréf með lágt $\mathrm{V} / \mathrm{H}-$ hlutfall skiluðu mun hærri ávöxtun en önnur hlutabréf og var sá munur marktækur. Hlutabréf lítilla fyrirtækja og hlutabréf með lágt q-hlutfall skiluðu einnig hærri ávöxtun en önnur hlutabréf en sá munur var ekki marktækur. Aftur á móti mældist ekkert samband á milli arðhlutfalls, sögulegrar frammistöðu og ávöxtunar.
\end{abstract}

\begin{abstract}
This study examines the relationship between P/E-ratio, q-ratio, dividend yield, historical returns, company size and returns of Icelandic stocks. The study uses monthly return data of stocks from the Iceland Stock Exchange from January 1993 to June 2003. The methodology is based on building portfolios on the basis of the above variables. Every month, from January 1993 to June 2003, the stocks in the sample were ranked according to the variable examined and then grouped into four portfolios. The performance of each portfolio was then measured and compared both in absolute terms and correcting for systematic risk. The results are that returns on stocks with a low P/E-ratio were much substantially higher than returns on other stocks and this difference was statistically significant. The returns of small stocks and stocks with a low q-ratio were higher than that of other stocks but this difference was not statistically significant. No relationship was detected between returns and historical returns, and between returns and dividend yield.
\end{abstract}

JEL-flokkun: G12; G14

Lykilhugtök: skilvirkni, íslenskur hlutabréfamarkaður, V/H-hlutfall

\footnotetext{
${ }^{1}$ Ásgeir Jónsson er lektor við viðskipta- og hagfræðideild Háskóla Íslands. Stefán B. Gunnlaugsson er lektor við viðskiptadeild Háskólans á Akureyri. Birgi Guðmundssyni, Bjarna G. Hjarðar og tveimur nafnlausum ritrýnum eru færðar pakkir fyrir gagnlegar ábendingar. Starfsmönnum Kauphallar Íslands eru færðar bakkir fyrir aðstoð við gagnaöflun.
} 


\section{Inngangur}

Раð hefur löngum verið ósk fjárfesta að geta slegið markaðinum við og náð betri ávöxtun en par pekkist að meðaltali. Athyglin hefur einkum beinst að nokkrum einföldum kennitölum við val á hlutabréfum til pess að ná svokallaðri umframávöxtun, en pað er ávöxtun umfram „eðlilegt“ áhættuálag á markaði. Nokkrar mikilvægustu kennitölurnar eru: stærð fyrirtækja, arðgreiðslur, V/H-hlutfall (markaðsverð/hagnaður), q-hlutfall (markaðsverð/eigið fé) og frammistaða (söguleg ávöxtun). Niðurstöður margra erlendra rannsókna hafa sýnt að fjárfesting byggð á pessum einföldu kennitölum skilar oft góðum árangri, betri en gengur og gerist að meðaltali á viðkomandi markaði. Aftur á móti hafa litlar sem engar rannsóknir verið gerðar á tengslum ofangreindra kennitalna og ávöxtunar á íslenska hlutabréfamarkaðinum. Рað er ef til vill skiljanlegt í ljósi pess að hann er mun yngri en erlendir hlutabréfamarkaðir, en tiltölulega stutt er síðan nægilega langar gagnaraðir lágu fyrir hérlendis til að mögulegt væri að framkvæma nákvæm tölfræðipróf.

Í pessari grein verða raktar niðurstöður viðamikillar rannsóknar á íslenska hlutabréfamarkaðinum frá ársbyrjun 1993 til loka júní 2003. Kannað var hvort ofangreindar kennitölur gætu skilað umframávöxtun ef pær væru notaðar við val á hlutabréfum, líkt og raunin hefur verið á erlendum mörkuðum. Einnig var kannað hvort ávöxtun hefði verið „óeðlileg“ að teknu tilliti til áhættu.

Ljóst er að möguleikinn á umframávöxtun hlýtur ávallt að velta á skilvirkni hlutabréfamarkaðsins, p.e. flæði upplýsinga og nýtingu peirra. En ef notkun ofangreindra kennitalna getur raunverulega skilað umframávöxtun má jafnframt velta fyrir sér af hverju fjárfestar á markaði hafa ekki pegar fært sér pað í nyt. Af peim sökum eru líkurnar á umframávöxtun með aðstoð ofangreindra viðmiða að einhverju leyti próf á skilvirkni markaðsins (Campbell o.fl., 1997). Hins vegar getur hugtakið skilvirkni haft misjafna pýðingu. Á fullkomlega skilvirkum markaði er viðskiptakostnaður enginn og hægt er að afla upplýsinga án kostnaðar og ómögulegt er að slá markaðinum við. Ástæðan er einfaldlega sú að allar upplýsingar sem skipta máli og eru til staðar hafa pegar verið teknar til greina og metnar til fjár af markaðsaðilum. Af peim sökum ætti markaðsverðið ætíð að endurspegla allt sem skiptir máli fyrir virði fyrirtækja á markaði á hverjum tíma. Hins vegar verða pessi skilyrði að teljast fremur ströng og í nokkurri andstöðu við raunveruleikann. Yfirleitt er notast við veikari og raunhæfari skilyrði um skilvirkni og pá er gert ráð fyrir að hlutabréfaverð innihaldi upplýsingar að pví marki að jaðarávinningur pess að nýta upplýsingarnar til að hagnast sé ekki meiri en viðskiptakostnaður.

Niðurstöður pessarar rannsóknar staðfesta að nokkru leyti niðurstöður sambærilegra rannsókna sem gerðar hafa verið á erlendum mörkuðum. Mjög sterk tölfræðileg tengsl mælast á milli V/H-hlutfalls og ávöxtunar en nokkru veikari á milli annarra pátta, einkum stærðar og q-hlutfalls. Samband V/H-hlutfalls og ávöxtunar gæti sýnt að fjárfestum hérlendis hættir hugsanlega til pess að ofmeta möguleika vaxtarfyrirtækja. Tiltölulega veikt samband á milli ávöxtunar og annarra pátta gæti haft prípætta pýðingu. Í fyrsta lagi gæti petta bent til pess að íslenski hlutabréfamarkaðurinn sé prátt fyrir allt nokkuð skilvirkur par sem einfaldar kennitölur við hlutabréfakaup duga ekki til pess að ná umframávöxtun. Í öðru lagi gætu niðurstöðurnar einnig bent til pess að íslenski hlutabréfamarkaðurinn sé 
einfaldlega of smár og takmarkaður til pess að mörg pessara stefnumiða hafi sömu pýðingu og erlendis. Íslensk fyrirtæki eru til að mynda fremur lítil á alpjóðlegum mælikvarða og vægi atvinnugreina á hlutabréfamarkaði annað en pekkist erlendis og pað gæti haft áhrif á allan samanburð, til dæmis samanburð á ávöxtun og q-hlutfalli, sem er mjög mismunandi eftir atvinnugreinum. Í priðja lagi er ekki hægt að útiloka að tímaröðin sem rannsökuð er sé ekki nógu löng til að marktækar niðurstöður fáist.

Að lokum má velta fyrir sér hvort hægt sé að hagnast á niðurstöðum pessarar rannsóknar. Ljóst er að sú fjárfestingarstefna að kaupa hlutabréf í fyrirtækjum með

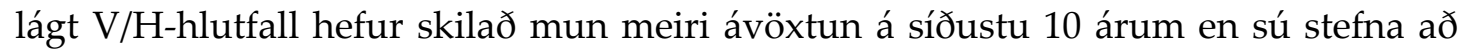
kaupa fyrirtæki með hátt V/H-hlutfall. Meðalávöxtun hlutabréfasafns með lægstu V/H-hlutföllin var 2,25\% á mánuði en til samanburðar má nefna að meðalávöxtun úrvalsvísitölunnar var einungis 1,11\%. ó verður að taka mið af pví að í pessari rannsókn eru arðgreiðslur metnar til ávöxtunar en pað er ekki gert pegar úrvalsvísitalan er reiknuð. Hins vegar er rétt að setja fram tvo varnagla um hagnýtt gildi pessarar rannsóknar. Í fyrsta lagi er hér um sögulega ávöxtun að ræða. Hröð frampróun hefur átt sér stað á íslenskum hlutabréfamarkaði á síðustu 10 árum og hluti gagnanna er frá peim tíma er markaðurinn var enn á bernskuskeiði og pað kann að skekkja niðurstöður fyrir allt tímabilið. Í öðru lagi felst aðferðafræði rannsóknarinnar í pví að búa til verðbréfasöfn í hverjum einasta mánuði eftir peim kennitölum sem rannsakaðar eru en verulegur viðskiptakostnaður leggst til ef verðbréfasafni peirra félaga sem væru með lægst V/H-hlutfall er ávallt haldið við í hverjum mánuði. Engu að síður eru pessar niðurstöður pað afgerandi að íslenskir fjárfestar gætu haft ástæðu til pess að gefa V/H-hlutfalli fyrirtækja nánari gaum við val á hlutabréfum en peir hafa gert.

\section{2. Íslenski hlutabréfamarkaðurinn}

Раð er erfiðleikum háð að finna góða aðferðafræði við rannsókn á íslenska hlutabréfamarkaðinum. Ástæðan er einkum sú að virk viðskipti á markaðinum ná einungis til mjög fárra félaga í alpjóðlegum samanburði og stutt er síðan markaðurinn komst á legg. Enn fremur er ljóst að sumir mælikvarðar, eins og t.d. stærð fyrirtækja, hljóta ávallt að vera nokkuð afstæðir par sem nær öll íslensk fyrirtæki eru smá í alpjóðlegum samanburði og stærðardreifing jafnari en pekkist erlendis.

Segja má að skipulögð hlutabréfaviðskipti hérlendis hafi fyrst hafist árið 1985 en pá fór Hlutabréfamarkaðurinn hf. að kaupa og selja hlutabréf fyrir eigin reikning. Nokkrar aðrar tilraunir sem runnu út í sandinn höfðu áður verið gerðar. Landsbanki Íslands rak t.d. kauphöll um nokkurt skeið um miðbik tuttugustu aldar. Árið 1986 hófst starfsemi Verðbréfapings Íslands sem síðar varð Kauphöll Íslands. Verðbréfapingið var fyrstu árin hjá Seðlabanka Íslands en allt til ársins 1990 var einkum verslað með ríkisskuldabréf á pinginu en ekki hlutabréf (Kauphöll Íslands, Árbók 2003).

Próun úrvalsvísitölunnar, sem dregin er upp á mynd 1, sýnir vel að íslenski hlutabréfamarkaðurinn hefur gefið góða ávöxtun á síðustu 10 árum. Árleg meðalhækkun úrvalsvísitölunnar frá árslokum 1999 til ársloka 2003 er 20,5\% og pví hefur íslenski hlutabréfamarkaðurinn gefið afburða ávöxtun. Frá árinu 1993 hefur hlutabréfaverð á markaðinum einungis lækkað tvö ár, árin 2000 og 2001. 


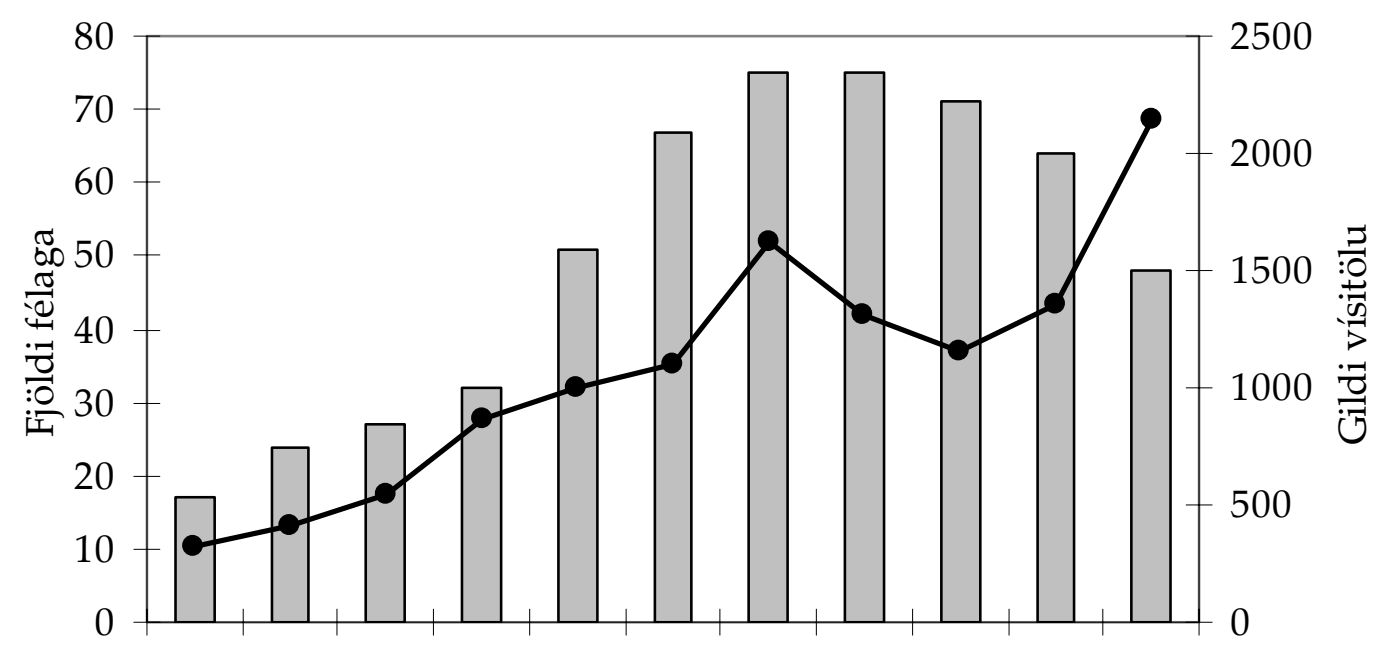

19931994199519961997199819992000200120022003

Mynd 1. Fjöldi skráđra hlutafélaga í Kauphöll Íslands og próun úrvalsvísitölunnar 1993-2003 (Heimild: Kauphöll Íslands).

Fjöldi skráðra hlutafélaga í Kauphöllinni virðist hafa náð hámarki um síðustu aldamót. Í árslok 1993 voru 17 hlutafélög skráð í Kauphöllinni en síðan fjölgaði peim ár frá ári allt til ársins 1999 pegar 75 hlutafélög voru skráð á markaði. Frá peim tíma hefur skráðum hlutafélögum fækkað verulega en pau voru 40 um mitt ár 2004. Aftur á móti hefur bæði velta og markaðsvirði vaxið verulega frá 1993 prátt fyrir fækkun félaga á síðustu 5 árum. Heildarmarkaðsverð skráðra félaga var einungis 19 ma. kr. 1993 en hafði aukist í 659 ma. kr. í árslok 2003, og pað sést vel á mynd 2. Á sama tíma jukust viðskipti með hlutabréf úr 0,8 ma. kr. árið 1993 í 554 ma. kr. árið 2003. Рað verður raunar að teljast proskamerki að velta á markaðinum hefur aukist á sama tíma og fjöldi skráðra félaga hefur dregist saman, en pað pýðir að meðalvelta hvers félags hefur aukist verulega. Af peim sökum ættu íslensk hlutabréf að vera mun seljanlegri en áður og pví ætti markaðurinn að hafa dýpkað og verðmyndun að hafa orðið skilvirkari. 


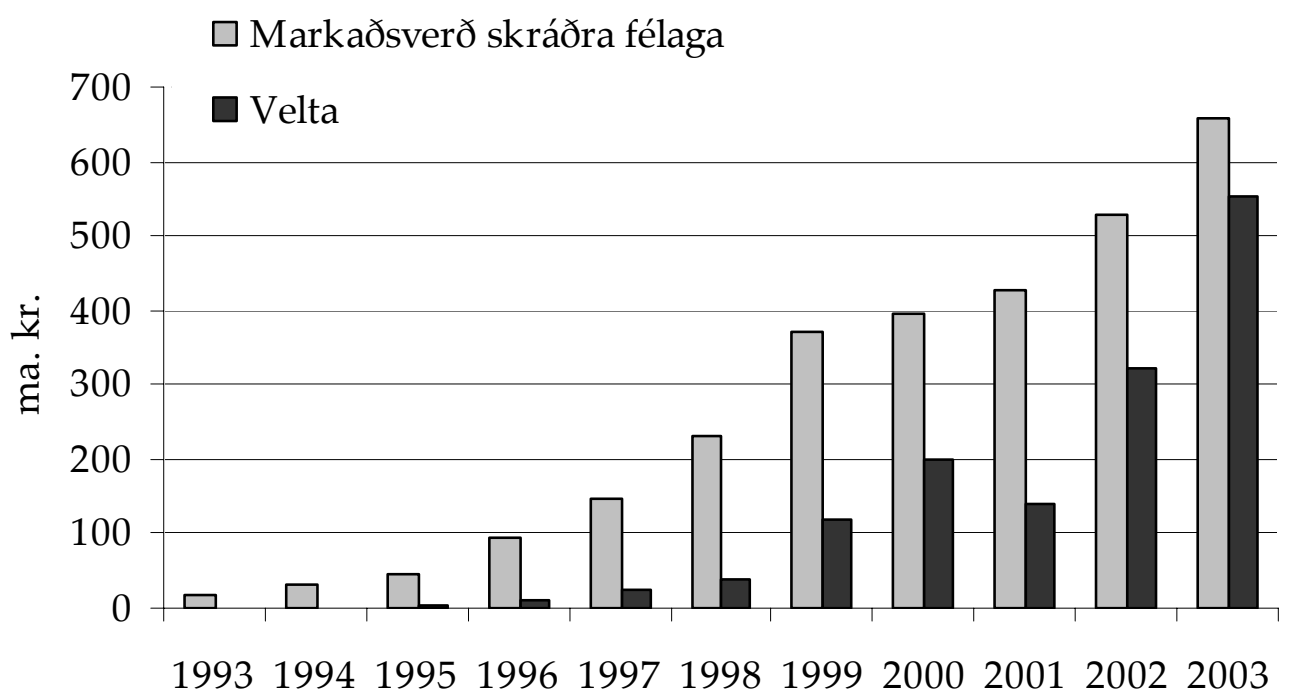

Mynd 2. Markaðsverð og velta skráðra hlutabréfa í Kauphöll Íslands 1993-2003 (Heimild: Kauphöll Íslands).

\section{Aðferðafræði}

Sú aðferðafræði sem varð fyrir valinu við framkvæmd pessarar rannsóknar byggist á pví að búa til verðbréfasöfn (e. portfolios) eftir peim páttum sem rannsakaðir eru og bera saman ávöxtun peirra. Einnig eru framkvæmd tölfræðipróf par sem kannað er hvort marktækur munur sé á ávöxtun verðbréfasafnanna að teknu tillit til mismunar á áhættu peirra. Sem dæmi má taka að pegar kannað var samband markaðsverðs og ávöxtunar voru mynduð fjögur verðbréfasöfn í byrjun hvers mánaðar sem rannsóknin náði yfir par sem fyrirtækin voru flokkuð eftir stærð. Í safni númer 1 voru minnstu félögin, síðan örlítið stærri félög í safni 2, enn stærri í safni 3 og í safni 4 voru stærstu félögin. Frammistaða (ávöxtun) safnanna var síðan mæld í mánuðinum og höfðu öll félög jafnt vægi. Í næsta mánuði voru síðan aftur búin til verðbréfasöfn og ávöxtun peirra mæld og síðan koll af kolli.

Tímabilið sem pessi rannsókn spannar er frá ársbyrjun 1993 til loka júní 2003 og voru pví búin til 504 verðbréfasöfn við rannsóknir á hverjum pætti. Í úrtaki rannsóknarinnar eru 20 hlutafélög árið 1993, 24 árið 1994 og frá ársbyrjun 1995 til júní 2003 eru 28 félög. ${ }^{2}$ Val félaganna var háð tilviljunum en pó var pess gætt að allar atvinnugreinar ættu par fulltrúa. Eðlilega urðu verulegar breytingar á markaðinum á

\footnotetext{
2 Eftirfarandi félög voru í pessu úrtaki: Búnaðarbankinn, Eignarhaldsfélagið Alpýðubankinn, Eimskip, Flugleiðir, Grandi, Hampiðjan, Haraldur Böðvarsson, Hraðfrystihús Eskifjarðar (Eskja), Íslenskar sjávarafurðir, Íslandsbanki, Íslandssími, Jarðboranir, Kaupping, Landsbankinn, Lyfjaverslun Íslands, Marel, Nýherji, Olíuverslun Íslands, Olíufélagið, Pharmaco, Sameinaðir verktakar, Samherji, Sölumiðstöð hraðfrystihúsanna, SÍF, Síldarvinnslan, Sjóvá-Almennar, Skagstrendingur, Skeljungur, Skinnaiðnaður, Skýrr, SR-mjöl, Sæplast, Tæknival (Aco-Tæknival), Útgerðarfélag Akureyringa, Pormóður rammi - Sæberg og Próunarfélagið.
} 
pessu tímabili sem rannsóknin nær yfir. Viðskipti með ný fyrirtæki hefjast á markaðinum og fyrirtæki detta út af ýmsum ástæðum. Vegna pessa eru nokkru fleiri félög í pessu úrtaki, 36, heldur en raðað er í verðbréfasöfnin, en par eru flest 28 félög. Reynt er að hafa safn félaganna eins stöðugt og hægt er, p.e. félög eru ekki tekin út úr rannsókninni fyrr en viðskipti með pau í Kauphöllinni hætta.

Sú aðferðafræði sem hér er beitt er næstum pví sú sama og Jahnke o.fl. (1987) notuðu til að greina frammistöðu hlutabréfa út frá V/H-hlutfalli peirra með pví að bera saman frammistöðu (ávöxtun) tveggja verðbréfasafna. Helsti galli pessarar aðferðafræði er sá að hugsanlegt er að einhverjar pær breytur sem kannaðar voru hafi verið tölfræðilega háðar. Til dæmis er hugsanlegt að samband hafi verið á milli stærðar fyrirtækja og V/H-hlutfalls eða á milli arðhlutfalls og q-hlutfalls. Til pess að komast hjá pessu vandamáli hefði verið nauðsynlegt að vera með mun fleiri hlutafélög í úrtakinu svo að hægt hefði verið að raða peim í verðbréfasöfn með hliðsjón af tveimur breytum samtímis. Til dæmis hefði purft að byrja á pví að raða hlutafélögunum í verðbréfasöfn eftir stærð og síðan hverju verðbréfasafni innan hvers stærðarflokks eftir V/H-hlutfalli ef kanna hefði átt hvort samband væri á milli V/H-hlutfalls og stærðar fyrirtækja. Hins vegar eru of fá félög á markaði hérlendis svo hægt sé að beita peirri aðferðafræði.

Pau tölfræðipróf sem hér eru notuð byggja á hinu klassíska CAPM-líkani og mæla ávöxtun sem er umfram pað sem líkanið getur skýrt. Grunnurinn að CAPM líkaninu var lagður af Markowitz (1959), en í rannsóknum sínum sýndi hann fram á að fjárfestar reyna að vega saman áhættu og arðsemi í pví að byggja upp safn verðbréfa sem skilar sem mestri ávöxtun með sem minnstum breytileika (e. variance). Líkanið var síðar mótað í núverandi mynd af Sharpe (1964) og Lintner (1965), en peir sýndu m.a. fram á að besta verðbréfasafnið væri pað safn er væri samsett af bréfum af öllum fjármálamörkuðum heimsins og gæfi hæsta ávöxtun út frá dreifni (e. mean-variance efficient portfolio), p.e ef fjárfestar hefðu eingerðar væntingar.

Reiknaður er $\alpha$-stuðull Jensens (táknaður með $\alpha_{p}$ ) sem var fyrst kynntur 1968 og er fundinn með aðhvarfsgreiningu á jöfnuna:

$$
R_{p t}-R_{f t}=\alpha_{p}+\beta_{p}\left(R_{m t}-R_{f t}\right)+u_{p t}
$$

Aðrar breytur sem hér koma fyrir eru $R_{p t}$ sem er ávöxtun verðbréfasafns $p$ í mánuði $t$ $(t=1, \ldots, 138), R_{f t}$ er áhættulausir vextir sem hér eru miðaðir við ávöxtunarkröfu priggja mánaða ríkisvíxla, $\beta_{p}$ er hallatala sem er jöfn kerfislægri áhættu verðbréfasafnsins $\left(\operatorname{COVAR}\left(R_{p t}, R_{m t}\right) / \sigma^{2}\right), R_{m t}$ er ávöxtun markaðsins og $u_{p t}$ er skekkjuliður. Ef sú forsenda er gefin að CAPM-módelið skýri ávöxtun hlutabréfa ætti $\alpha_{p}$-stuðull verðbréfasafna er hafa sömu samsetningu og vísitala markaðarins að vera núll. Pví bendir marktækur jákvæður $\alpha$-stuðull til pess að verðbréfasafn hafi skilað „óeðlilega“ góðri ávöxtun og neikvæður $\alpha$-stuðull til pess að ávöxtun hafi verið „óeðlilega" slök.

Til pess að bera saman ávöxtun tveggja eða fleiri safna var leppbreyta $\left(D_{p t}\right)$ notuð sem fær gildið 1 eða 0 eftir atvikum:

$$
R_{p t}-R_{f t}=\alpha_{p}+d_{L} D_{p t}+\beta_{P}\left(R_{m t}-R_{f t}\right)+s_{L} S_{p t}+u_{p t}
$$


Aðrar breytur eru pær sömu og áður utan $S_{p t}=D_{p t}\left(R_{m t}-R_{f t}\right)$ svokölluð hallaleppbreyta (e. slope dummy) en hún sýnir mun á kerfisbundinni áhættu verðbréfasafnanna.

Stuðullinn $d_{L}$ er lykilstuðull í aðhvarfsgreiningunni. Hann sýnir muninn á Jensens $\alpha$-stuðli verðbréfasafnanna og pví fær Jensens $\alpha$-stuðullinn $\alpha+d_{L}$ í verðbréfasafninu leppbreytu, p.e. $D_{p t}=1$. Pví er hægt að nota t-próf til að kanna hvort $d_{\mathrm{L}}$-stuðullinn sé marktækur. Ef hann er marktækur sýnir pað að marktækur munur hefur verið á ávöxtun verðbréfasafnanna pegar búið er að taka tillit til mismunar á áhættu peirra. Stuðullinn $\beta_{P}$ jafngildir kerfislægri áhættu $(\beta)$ verðbréfasafnsins, sem ekki fær leppbreytu, p.e. $D_{p t}=0$. Pví fær $\beta$-stuðull verðbréfasafnsins leppbreytu, p.e. leppbreytan $D_{p t}=1, \beta_{P}+s_{L}$.

Pær upplýsingar sem notaðar voru við pessa rannsókn voru fengnar úr ýmsum áttum. Kauphöll Íslands útvegaði gögn um verðpróun hlutabréfanna. Uppgjör félaganna voru fengin eftir ýmsum leiðum, á heimasíðu Kauphallarinnar, hjá gagnabanka Morgunblaðsins og einnig hjá félögunum sjálfum.

раð er pví ljóst að rannsóknin nær yfir mikið proskatímabil í íslenskum hlutabréfaviðskiptum en nú er töluvert öðruvísi umhorfs á hlutabréfamarkaði en var fyrir 10 árum. Vitaskuld ættu ákveðin grunneinkenni að hafa haldist á markaðinum, enda um tiltölulega stuttan tíma að ræða. Mestu skiptir pó að aðferðafræðin byggist á pví að raða saman hlutabréfasöfnum á hverjum tíma eftir ofangreindum viðmiðum og endurtaka röðunina strax aftur á næsta tímabili. Með slíkum hlutfallslegum samanburði innan tímabils ætti af peim sökum að nást að leiðrétta misræmi sem kemur til af ýmsum kerfisbreytingum sem átt hafa sér stað á íslenskum hlutabréfamarkaði. Pannig er ekki verið að bera saman V/H-hlutfall eða stærð fyrirtækja á milli ára heldur aðeins mismun á ávöxtun ef ákveðinni fjárfestingarstefnu er fylgt af samkvæmni á ákveðnu tímabili.

\section{Samband V/H-hlutfalls og ávöxtunar}

\subsection{Fyrri rannsóknir}

Tengsl V/H-hlutfalls (markaðsverðs/hagnaðar) og ávöxtunar hafa margfaldlega verið til skoðunar á helstu fjármálamörkuðum heimsins. Raunar má færa rök fyrir pví að samband pessarar kennitölu og ávöxtunar hafi oftar verið til skoðunar en nokkurt annað samband á hlutabréfamörkuðum. Pað er ef til vill engin furða ef haft er í huga að samkvæmt grunnforsendum um verðmat ætti virði fyrirtækja að vera jafnt og núvirtur hagnaður í framtíðinni. Hátt V/H-hlutfall hlutabréfs bendir pví til að miklar væntingar um vöxt hagnaðar séu innifaldar í verði hlutabréfsins. Margar rannsóknir hafa sýnt að ávöxtun félaga með lágt $\mathrm{V} / \mathrm{H}$-hlutfall hefur verið meiri en hlutabréfa er hafa lágt V/H hlutfall. Ástæðuna má líklega rekja til hins fornkveðna, að betri sé einn fugl í hendi en tveir í skógi. Fjárfestum hættir til að ofmeta möguleika vaxtarfyrirtækja og pað hefur leitt til pess að pau hafa ekki náð að standa undir pví verði sem pau hafa verið seld á og ávöxtun peirra hefur pví verið minni en meðaltalsávöxtun á markaðinum. 
Í viðamikilli rannsókn á hlutabréfamörkuðum í Bandaríkjunum, Pýskalandi, Frakklandi og Japan skoðuðu Haugen og Baker (1996) gögn frá 1985 til 1993. Peir komust að pví að hlutabréf fyrirtækja sem höfðu lágt V/H-hlutfall ávöxtuðust betur en önnur hlutabréf á öllum pessum mörkuðum á pessu tímabili, en mestur var munurinn í Bandaríkjunum og Frakklandi. Basu (1977) kannaði hvort ávöxtun hlutabréfa væri í samhengi við V/H-hlutfall peirra. Hann rannsakaði bandaríska hlutabréfamarkaðinn frá pví í september 1956 til ágúst 1971. Hann komst að pví að meðalávöxtun verðbréfasafns með lágt $\mathrm{V} / \mathrm{H}$-hlutfall var 13,5\% á ári en meðalávöxtun verðbréfasafns með hátt V/H-hlutfall var 9,5\%. Hærri ávöxtun var ekki skýrð með meiri áhættu en ekki var munur á kerfisbundinni áhættu (e. systematic risk) enda var kerfisbundin áhætta verðbréfasafnsins með lágt V/H-hlutfall lægri en hins safnsins. Rannsóknir á smærri hlutabréfamörkuðum hafa gefið svipaðar niðurstöður. Í rannsókn á suður-afríska hlutabréfamarkaðinum frá 1982 til 1998 kom í ljós að ávöxtun hlutabréfa með lágt V/H-hlutfall var mun meiri en annarra hlutabréfa. Meiri ávöxtun peirra var einkum rakin til fárra hlutabréfa, með lágt $\mathrm{V} / \mathrm{H}$-hlutfall, sem gáfu afburðaávöxtun (Rensburg og Rousseau, 2004).

\subsection{Rannsókn og niðurstöður}

Við útreikning á V/H-hlutfallinu var notað markaðsverð félaganna sem voru í úrtakinu. Hagnaður var skilgreindur sem hagnaður eftir óreglulega liði og skatta síðustu 12 mánuði á undan útreikningi. Uppgjör fyrirtækja voru ekki notuð fyrr en pau voru ljós fjárfestum. Sem dæmi má nefna að ef fyrirtækið birti uppgjör 15. apríl var niðurstaða pess ekki notuð við útreikning á V/H-hlutfallinu fyrr en 30. apríl. Dví er alveg öruggt að komið er í veg fyrir hina svokölluðu framsýnisvillu (e. look ahead bias). ${ }^{3}$

Til hægðarauka var V/H-hlutfallinu snúið við. Ástæður pessa eru að félög sem rekin eru með tapi, p.e. með neikvæðum hagnaði, fá pá sjálfkrafa lægsta $\mathrm{H} / \mathrm{V}$ hlutfallið og raðast pví með félögum sem eru rekin með hagnaði en hafa mjög hátt V/H-hlutfall. Í hverjum mánuði voru fjögur verðbréfasöfn búin til eftir H/V-hlutfalli í byrjun hvers mánaðar og ávöxtun peirra var síðan mæld í mánuðinum. Strax næsta mánuð á eftir voru ný verðbréfasöfn búin til og síðan koll af kolli. Notuð var aðhvarfsjafna (j. 2) og var borin saman ávöxtun og áhætta verðbréfasafnanna með hæsta og lægsta V/H-hlutfallið. Verðbréfasafnið með háa V/H-hlutfallið fékk leppbreytuna 1 en verðbréfasafnið með lága $\mathrm{V} / \mathrm{H}$-hlutfallið fékk leppbreytuna 0.

Niðurstöðurnar gefa til kynna að fjárfestar hefðu getað náð umframávöxtun með pví að huga sérstaklega að V/H hlutfallinu. Meðalávöxtun safnsins með hæsta V/H-hlutfall var einungis 1,01\% á mánuði (margfeldisávöxtun, e. geometric mean).

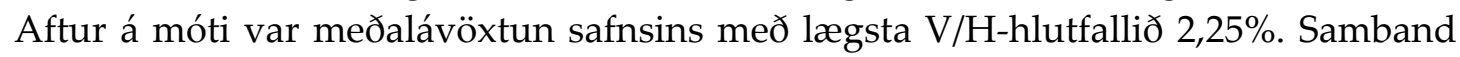
V/H-hlutfalls og ávöxtunar íslenskra hlutabréfa sést vel á mynd 3.

\footnotetext{
3 Pessi villa felst í pví að rannsakendur hafa notað upplýsingar við rannsóknir á fjármálamörkuðum sem ekki voru ljósar fjárfestum á peim tíma sem kannaður var.
} 


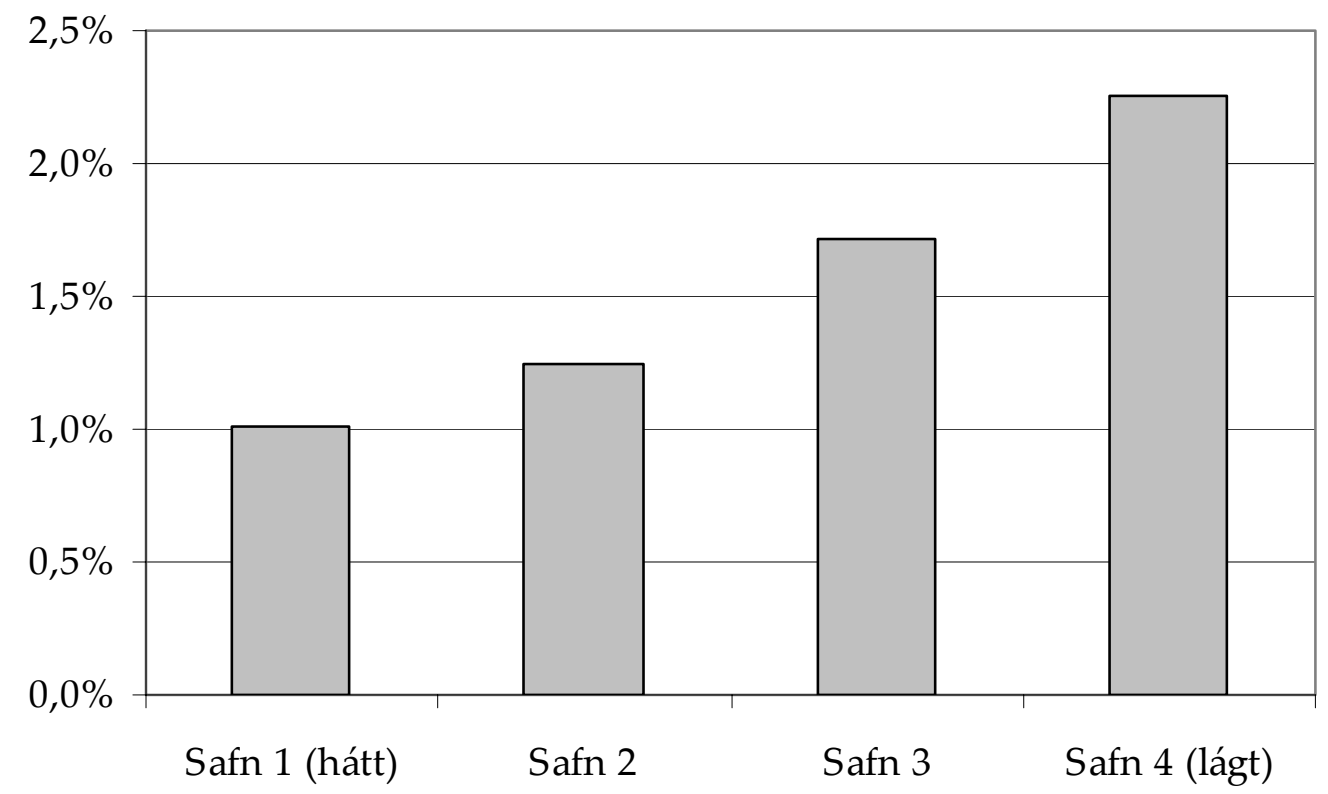

Mynd 3. Meðalávöxtun verðbréfasafna sem raðað er eftir V/H-hlutfalli peirra.

Раð sama má einnig lesa úr formlegum tölfræðiprófum en helstu niðurstöður aðhvarfsgreiningarinnar eru sýndar í töflu 1. Par sést að Jensens $\alpha$-stuðull verðbréfasafnsins með lága V/H-hlutfallið er áætlaður 0,0127. Jensens $\alpha$-stuðull safnsins með háa hlutfallið er áætlaður 0,001 $\left(\alpha_{P}+d_{L}\right)$. Marktækur munur er á Jensens $\alpha$-stuðli pessara tveggja verðbréfasafna pví að stuðullinn $d_{L}$ er marktækur. Pví er marktækur munur á ávöxtun safna 1 og 4 pegar búið er að taka tillit til áhættu peirra. pessu er pannig varið prátt fyrir að kerfisbundin áhætta safnsins með minni ávöxtunina sé nokkru minni en safnsins með meiri ávöxtunina sem sést á pví að $s_{L^{-}}$ stuðullinn, sem mælir mun á ávöxtun verðbréfasafnanna, er neikvæður. Durbin Watson stuðullinn er áætlaður 1,82 og pví verður ekki vart við marktæka fyrstu gráðu sjálffylgni (e. autocorrelation) sem bjagar niðurstöður.

Tafla 1. Helstu niðurstöður aðhvarfsgreiningar á verðbréfasöfnum sem raðað er eftir $\mathrm{V} / \mathrm{H}$-hlutföllum.

\begin{tabular}{lccccc}
\hline & $\alpha_{P}$ & $d_{L}$ & $\beta_{p}$ & $s_{L}$ & $R^{2}$ \\
\hline Stuðull & 0,013 & $-0,012$ & 0,89 & $-0,15$ & 0,43 \\
t-gildi & $\left({ }^{*} 3,16\right)$ & $\left({ }^{*}-2,06\right)$ & $\left({ }^{*} 10,03\right)$ & $(-1,23)$ & \\
p-gildi & 0,0018 & 0,041 & $<0,0001$ & 0,22 &
\end{tabular}

Durbin Watson $\quad 1,82$

* Marktækt miðað við 5\% marktektarkröfu.

Athygli vekur að Jensens $\alpha$-stuðlar bæði safns 1 og 4 eru jákvæðir. Petta stafar af pví að ávöxtun verðbréfasafnanna í pessari rannsókn er að meðaltali nokkru meiri en meðalávöxtun úrvalsvísitölunnar sem var að meðaltali $1,11 \%$ á mánuði 
(margfeldismeðaltal) frá ársbyrjun 1993 til loka júní 2003. Ástæður pessa eru eftirfarandi:

1. Í úrvalsvísitölunni er ekki tekið tillit til arðgreiðslna og pví mælir hún minni ávöxtun en í raun fæst á markaðinum. Í pessari rannsókn eru arðgreiðslur innifaldar í ávöxtun.

2. Nokkur tími líður frá pví að ný stór félög fara á markað og par til pau verða hluti af úrvalsvísitölunni. Oft hefur gengi á nýjum félögum hækkað mikið strax við skráningu og pví hefur úrvalsvísitalan að öllum líkindum mælt nokkuð lægri ávöxtun en raunverulegt meðaltal á markaðinum.

3. Vægi fyrirtækja í úrvalsvísitölunni fer eftir stærð peirra, sem mæld er í markaðsverðmæti peirra. Í pessari rannsókn hafa öll félög jafnt vægi. Seinna í pessari rannsókn kemur í ljós að lítil félög hafa skilað meiri ávöxtun en stór og pví gæti ávöxtun hafa verið vanmetin við útreikning úrvalsvísitölunnar.

4. Í úrvalsvísitölunni eru einungis 15 félög, en í stærstum hluta pessarar rannsóknar eru 28 félög í verðbréfasöfnunum. Pví er „breiðari“ ávöxtun mæld í pessari rannsókn en með úrvalsvísitölunni.

Prátt fyrir að $\alpha$-stuðlar Jensens séu jákvæðir hjá flestum verðbréfasöfnum pá skiptir pað ekki máli við mat á $d_{\mathrm{L}}$-stuðlinum. Sá stuðull mælir muninn á Jensens $\alpha$-stuðli safnanna og pví mælir hann hvort marktækur munur er á ávöxtun verðbréfasafnanna að teknu tilliti til kerfislægrar áhættu.

\section{Samband stærðar fyrirtækja og ávöxtunar:}

\subsection{Fyrri rannsóknir}

Við rannsóknir á hlutabréfamörkuðum er stærð fyrirtækja oftast mæld í markaðsvirði hlutabréfa peirra. Flestar rannsóknir víðast hvar hafa sýnt að ávöxtun lítilla fyrirtækja hefur almennt verið meiri en stórra fyrirtækja (Lofthouse, 1994).

Í ítarlegri rannsókn á bandaríska hlutabréfamarkaðinum frá 1963 til 1990, par sem búin voru til verðbréfasöfn út frá $\beta$-stuðlum og stærð fyrirtækjanna, kom í ljós að lítil fyrirtæki skiluðu betri ávöxtun en stór og var pað óháð $\beta$-gildum félaganna (Fama og French, 1992). Ástæðan fyrir pví að lítil fyrirtæki hafa gefið mjög góða ávöxtun hefur meðal annars verið talin stafa af meiri viðskiptakostnaði hjá litlum fyrirtækjum en stórum. Petta lýsir sér m.a. í pví að munur á kaup- og sölutilboðum er yfirleitt mun meiri hjá smáum fyrirtækjum fremur en stórum og pví er viðskiptakostnaður meiri. Meiri viðskiptakostnaður leiðir síðan til pess að fjárfestar gera hærri ávöxtunarkröfu, hlutabréfin verða ódýrari og ávöxtun verður meiri. Einnig má færa rök fyrir pví að lítil fyrirtæki starfi í öðrum greinum en stór fyrirtæki og gæti pað skýrt að hluta meiri ávöxtun. 


\subsection{Rannsókn og niðurstöður}

Búin voru til fjögur verðbréfasöfn í hverjum mánuði og var fyrirtækjum í úrtakinu skipað í pau eftir markaðsvirði. Ávöxtun safnanna er síðan mæld í hverjum mánuði og ný verðbréfasöfn búin til næsta mánuð á eftir. Auk pessa var gerð hefðbundin aðhvarfsgreining par sem jafna (j. 2) var notuð. Eins og sést á mynd 4 var ávöxtun pess verðbréfasafns best er hafði minnstu félögin innanborðs, mælt út frá markaðsvirði hlutafjár, og lökust hjá pví safni er hafði stærstu fyrirtækin. Meðalávöxtun minnstu fyrirtækjanna var rúmlega 1,9\% á mánuði en meðalávöxtun stærstu félaganna var $1,2 \%$.

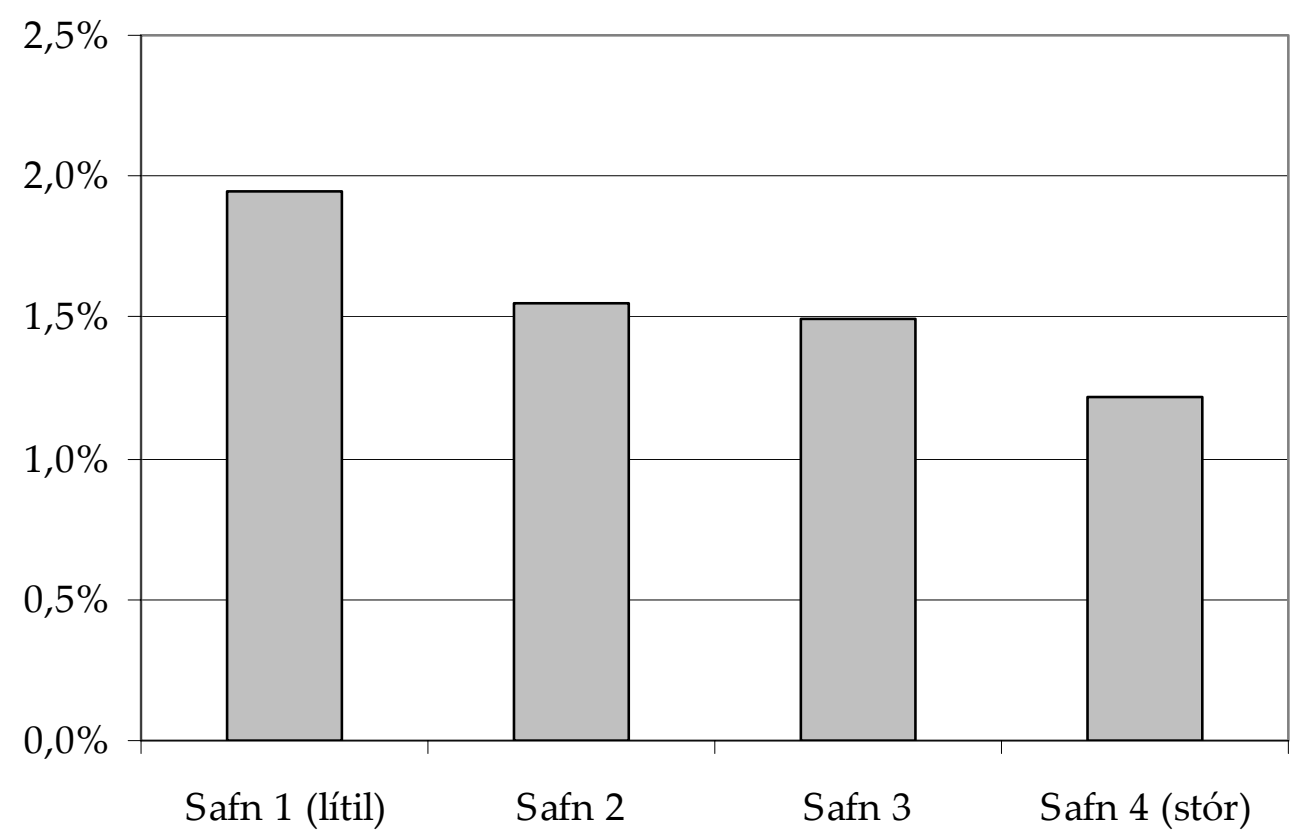

Mynd 4. Meðalávöxtun verðbréfasafna sem raðað er eftir stærð fyrirtækja.

Í ljós kemur að munurinn á ávöxtun pessara tveggja safna er of lítill til pess að vera tölfræðilega marktækur. Kerfisbundin áhætta safnsins ( $\beta$-gildi safnsins) sem sett var saman úr litlu fyrirtækjunum var minni en kerfisbundin áhætta safnsins með stóru félögunum. Petta sést á pví að sL-stuðullinn er neikvæður en $\beta$-stuðull verðbréfasafnsins sem samanstóð af litlu félögunum er $\left(\beta_{p}+s_{L}\right)$ og er pví 0,76. Prátt fyrir minni kerfisbundna áhættu og meiri ávöxtun safns 1 en 4 er samt ekki marktækur munur á ávöxtun safnanna að teknu tilliti til áhættu. Petta sést á stuðlinum $d_{L}$ en hann sýnir muninn á Jensens $\alpha$-stuðli safns 1 og 4 . $d_{\mathrm{L}}$-stuðullinn er 0,0089 en hann er ekki marktækur við 5\% marktektarkröfu. Pví er ekki marktækur munur á ávöxtun safnanna að teknu tilliti til áhættu. 
Tafla 2. Helstu niðurstöður aðhvarfsgreiningar á verðbréfasöfnum sem raðað er eftir stærð viðkomandi fyrirtækja.

\begin{tabular}{lccccc}
\hline & $\alpha_{P}$ & $d_{L}$ & $\beta_{p}$ & $s_{L}$ & $R^{2}$ \\
\hline Stuðull & 0,0015 & 0,0089 & 0,97 & $-0,21$ & 0,56 \\
t-gildi & $(0,45)$ & $(1,93)$ & $\left({ }^{*} 14,03\right)$ & $\left({ }^{*}-2,13\right)$ & \\
p-gildi & 0,65 & 0,054 & $<0,0001$ & 0,034 &
\end{tabular}

Durbin Watson $\quad 1,90$

* Marktækt miðað við 5\% marktektarkröfu.

Pessar niðurstöður eru nokkurn veginn í samræmi við rannsóknir á erlendum hlutabréfamörkuðum. Rannsóknin gefur til kynna að ávöxtun stærri fyrirtækja á íslenskum hlutabréfamarkaði hafi verið að meðaltali minni en ávöxtun smærri fyrirtækja pað tímabil sem rannsóknin nær yfir. Hins vegar er ekki tölfræðilega marktækur munur á ávöxtun að teknu tilliti til mismunar á kerfisbundinni áhættu.

\section{Samband ávöxtunar og arðgreiðslna}

\subsection{Fyrri rannsóknir}

Pegar samband arðgreiðslna og ávöxtunar hefur verið tekið til skoðunar í erlendum rannsóknum er arðhlutfallið (e. dividend yield) yfirleitt notað sem er hlutfall arðgreiðslna af markaðsverði. Ef arðhlutfallið er $2 \%$ pýðir pað að arður eiganda hlutafjár er $2 \%$ á ári af markaðsvirði fyrirtækisins.

Margar rannsóknir hafa verið gerðar á sambandi arðgreiðslna og ávöxtunar á erlendum hlutabréfamörkuðum. Yfirleitt hefur niðurstaðan verið sú að hlutabréf með hátt arðhlutfall hafa gefið betri ávöxtun en önnur. Í rannsókn á bandaríska hlutabréfamarkaðinum frá ársbyrjun 1927 til árloka 1976 rannsökuðu Elton o.fl. (1983) samband ávöxtunar og arðgreiðslna og fundu marktækt samband. Ef miðað var við félög sem á annað borð greiddu arð var ávöxtun hlutabréfa peirra peim mun hærri eftir pví sem arðhlutfallið var hærra. Levis (1989) komst einnig að pví í rannsókn sem hann gerði á breska hlutabréfamarkaðinum, og náði yfir tímabilið apríl 1961 til mars 1985, að hlutabréf með hátt arðhlutfall skiluðu bestri ávöxtun að teknu tilliti til áhættu. Raunar skoðaði Levis margar breytur og samhengi peirra við ávöxtun. Hann komst að pví að mest tengsl voru við arðhlutfallið af öllum breytum sem hann skoðaði.

Pau rök sem helst hafa verið gefin fyrir góðri ávöxtun hlutabréfa með hátt arðhlutfall eru að fjárfestar vilji að fyrirtæki greiði mikinn arð ef pað er ekki talið búa yfir miklum vaxtarmöguleikum. Pví eru fyrirtæki með lágt arðhlutfall oft vaxtarfyrirtæki. Reynslan hefur sýnt að fjárfestar ofmeta vaxtarmöguleika vaxtarfyrirtækja og pess vegna er ávöxtun peirra oft slök og ávöxtun fyrirtækja með miklar arðgreiðslur oft betri en annarra. 


\subsection{Rannsóknaraðferðir og niðurstöður}

Notuð var sama aðferðafræði og hér er lýst að ofan við gerð verðbréfasafna og tölfræðipróf. Á mynd 5 sést meðalávöxtun verðbréfasafnanna. Ávöxtun safns 1 var mest eða $1,9 \%$ á mánuði að meðaltali. Í safni 1 eru hlutabréf sem hafa lægst arðhlutfall en yfirleitt samanstóð petta safn eingöngu af hlutabréfum sem ekki var greiddur arður af. Athyglisvert er að safn 4 hafði næstmesta ávöxtun eða 1,8\% að meðaltali á mánuði. Í safni 4 eru hlutabréf með hæst arðhlutfall. Safn 3 er með minnsta ávöxtun og verður pví að álykta af mynd 5 að ekkert samband hafi verið á milli ávöxtunar og arðgreiðslna á íslenskum hlutabréfamarkaði á tímabilinu sem rannsakað var.

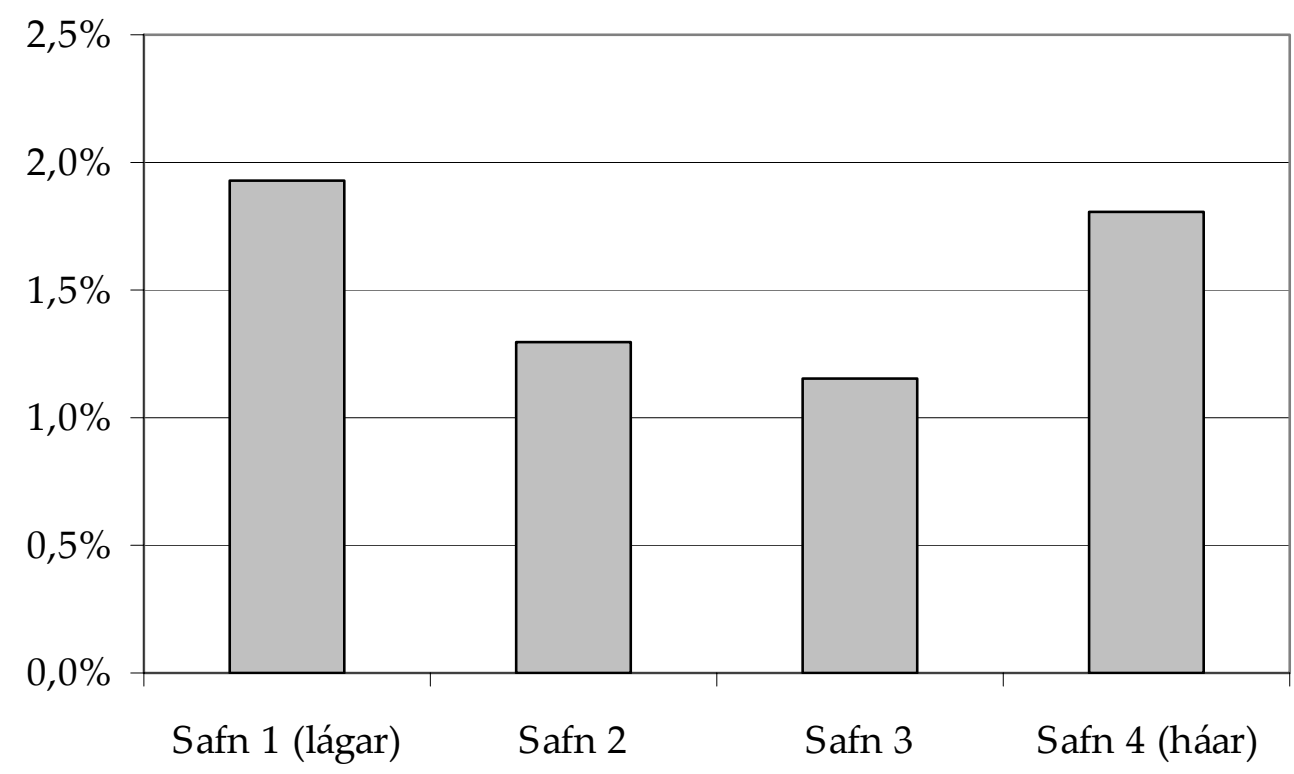

Mynd 5. Meðalávöxtun verðbréfasafna sem raðað er eftir arðhlutfalli.

Sú niðurstaða er einnig studd með formlegri tölfræðigreiningu. Í töflu 3 eru helstu niðurstöður aðhvarfsgreiningarinnar sýndar. Par kemur í ljós að nær enginn munur er á milli Jensens $\alpha$-stuðla safns 1 og safns 4 og pví er $d_{\mathrm{L}}$-stuðullinn ekki marktækur. Pví má einnig fullyrða út frá formlegri tölfræðigreiningu að ekkert samband hafi verið milli ávöxtunar og arðgreiðslna á íslenskum hlutabréfamarkaði á pví tímabili sem rannsóknin náði yfir.

Tafla 3. Helstu niðurstöður aðhvarfsgreiningar á verðbréfasöfnum sem raðað er eftir arðhlutfalli.

\begin{tabular}{lccccc}
\hline & $\alpha_{P}$ & $d_{L}$ & $\beta_{p}$ & $s_{L}$ & $R^{2}$ \\
\hline Stuðull & 0,0083 & 0,0015 & 0,79 & 0,14 & 0,46 \\
t-gildi & $(2,09)$ & $(0,26)$ & $\left({ }^{*} 9,37\right)$ & $(1,19)$ & \\
p-gildi & 0,037 & 0,79 & $<0,0001$ & 0,23 & \\
& & & & \\
Durbin Watson & 1,84 & & & \\
\multicolumn{7}{l}{${ }^{*}$ Marktækt miðað við 5\% marktektarkröfu. } \\
\hline
\end{tabular}




\section{Samband ávöxtunar og q-hlutfalls}

\subsection{Fyrri rannsóknir}

Kennitalan q-hlutfall er einfaldlega hlutfall markaðsvirðis fyrirtækisins á móti bókfærðu eigin fé. Til að mynda pýðir q-hlutfallið 3 að markaðsverð hlutafjár félagsins er prefalt hærra en eigið fé pess. Margar rannsóknir hafa verið gerðar á sambandi ávöxtunar hlutabréfa og q-hlutfalls peirra. Almennt hafa pær sýnt að hlutabréf fyrirtækja með lágt q-hlutfall hafa gefið betri ávöxtun en hlutabréf fyrirtækja með hátt q-hlutfall.

Í viðamikilli rannsókn Haugens og Bakers (1996) voru skoðuð gögn frá Bandaríkjunum, Pýskalandi, Frakklandi, Bretlandi og Japan frá 1985 til 1993. Peir komust að pví að hlutabréf í fyrirtækjum með lágt q-hlutfall skiluðu hærri ávöxtun en meðaltal markaðsins í öllum löndunum sem rannsóknin náði yfir. Pessi munur var tölfræðilega marktækur að teknu tilliti til mismunandi áhættu. Í nýlegri rannsókn (Chan og Lakonishok, 2004) var bandaríski hlutabréfamarkaðurinn rannsakaður frá 1979 til 2002. Niðurstöður Chans og Lakonishoks voru að hlutabréf fyrirtækja með lágt q-hlutfall skiluðu mun betri ávöxtun að meðaltali en annarra fyrirtækja. Auk pess voru pau áhættuminni en hlutabréf fyrirtækja með hátt q-hlutfall en áhættu mældu peir með staðalfráviki ávöxtunar.

Ástæða fyrir góðri ávöxtun fyrirtækja með lágt q-hlutfall hefur einkum verið rakin til mismunandi q-hlutfalls atvinnugreina. Atvinnugreinar með lágt q-hlutfall eins og t.d. bankar og fjármálafyrirtæki hafa oft skilað betri ávöxtun en önnur fyrirtæki. Einnig hafa vaxtarfyrirtæki yfirleitt hátt q-hlutfall en eins og áður hefur komið fram hefur ávöxtun peirra yfirleitt verið slök.

\subsection{Rannsókn og niðurstöður}

Búin voru til fjögur verðbréfasöfn í hverjum mánuði. Í safni 1 voru pau hlutabréf í úrtakinu sem höfðu lægsta q-hlutfall í byrjun mánaðar, síðan koll af kolli, og í safni 4 eru pau hlutabréf sem höfðu hæst q-hlutfall. Eins og sést á mynd 6 mældist meðalávöxtun mest í pví hlutabréfasafni er hafði lægst q-hlutfall eða um 1,85\% að meðaltali á mánuði. Ávöxtun safna 3 og 4 var svipuð eða um 1,3\% að meðaltali á mánuði. Pví var ávöxtun hlutabréfa í fyrirtækjum með lágt q-hlutfall nokkru hærri en annarra bréfa. 


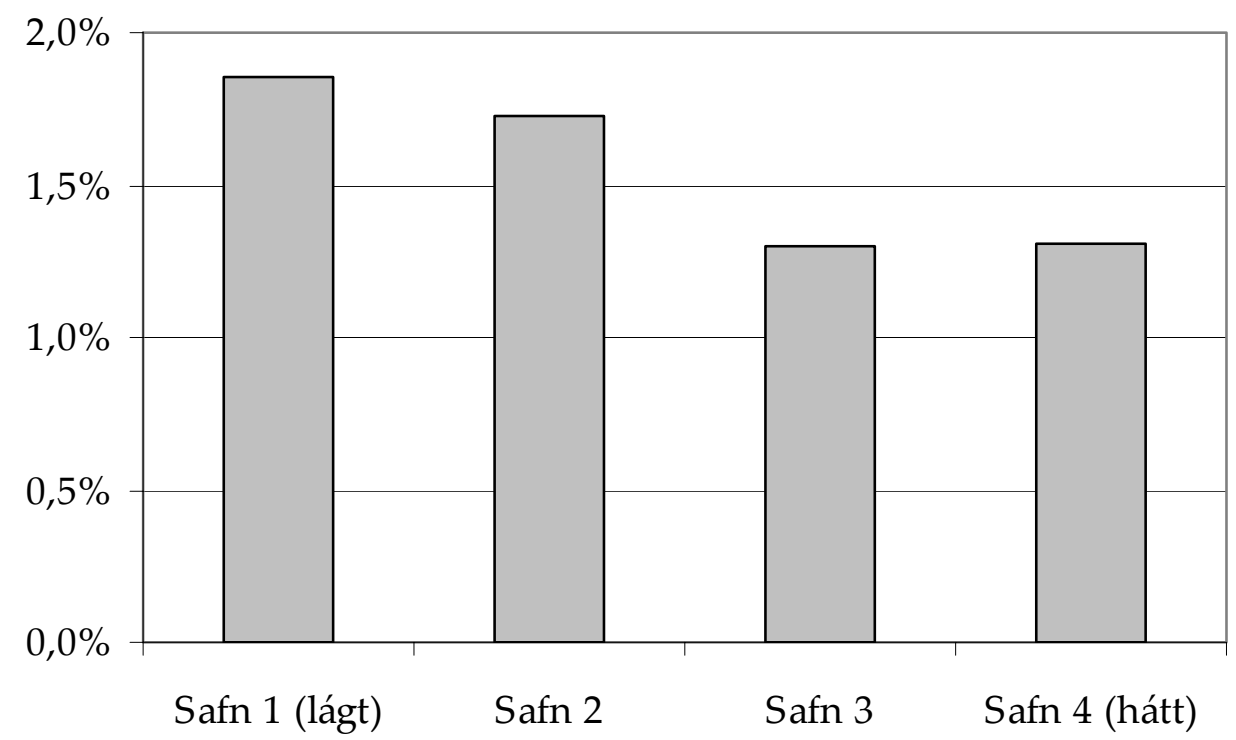

Mynd 6. Meðalávöxtun verðbréfasafna sem raðað er eftir q-hlutfalli.

Hins vegar var ekki hægt að sýna fram á tölfræðilega marktækan mun á ávöxtun verðbréfasafnanna miðað við q-hlutfall að teknu tilliti til mismunar á kerfisbundinni áhættu. Notuð var aðhvarfsjafna (j. 2) til að mæla hvort marktækur munur væri á ávöxtun safna 1 og 4 að teknu tilliti til kerfislægrar áhættu. Í töflu 4 eru sýndar niðurstöður aðhvarfsgreiningarinnar. Par kemur fram að ekki var marktækur munur á Jensens $\alpha$-stuðlum verðbréfsafns 1 og 4 enda er $\mathrm{d}_{\mathrm{L}}$-stuðullinn ekki marktækur. Dví var ekki marktækur munur á ávöxtun safna 1 og 4 að teknu tilliti til mismunandi kerfisbundinnar áhættu safnanna ( $\beta$-stuðuls safnanna). Athyglisvert er að marktækur munur er á kerfisbundinni áhættu safns 1 og safns 4 . Рað sést á sL-stuðlinum en hann mælir mun á $\beta$-stuðlum safns 1 og 4. SL-stuðullinn er marktækur og var pví kerfisbundin áhætta marktækt minni í safni 1 en safni 4 .

Tafla 4. Helstu niðurstöður aðhvarfsgreiningar á verðbréfasöfnum sem raðað er eftir q-hlutfalli.

\begin{tabular}{lccccc}
\hline & $\alpha_{P}$ & $d_{L}$ & $\beta_{p}$ & $s_{L}$ & $R^{2}$ \\
\hline Stuðull & 0,0029 & 0,00653 & 1,04 & $-0,33$ & 0,47 \\
t-gildi & $(0,73)$ & $(1,17)$ & $\left({ }^{*} 12,22\right)$ & $\left({ }^{*}-2,76\right)$ & \\
p-gildi & 0,46 & 0,245 & $<0,0001$ & 0,006 &
\end{tabular}

Durbin Watson $\quad 2,07$

* Marktækt miðað við 5\% marktektarkröfu. 


\section{Samband ávöxtunar og fyrri frammistöðu}

\subsection{Fyrri rannsóknir}

Ýmsar erlendar rannsóknir hafa bent til pess að ávöxtun hlutabréfa sé að nokkru tengd ávöxtun síðustu missera á undan viðmiðunartíma. Раð pýðir að hlutabréf sem hafa gefið góða ávöxtun í fortíðinni séu ekki jafnlíkleg til pess að gefa góða ávöxtun í framtíðinni og pau bréf sem gáfu slæma ávöxtun í fortíðinni. Sú ástæða sem gefin hefur verið fyrir pessu er að viðbrögð fjárfesta við nýjum upplýsingum séu oft yfirdrifin. Pví verði viðbrögð markaðsins við nýjum góðum fréttum of mikil, verð hlutabréfa hækki pví of mikið en leiðréttist (lækki) svo.

Til að mynda rannsökuðu De Bondt og Thaler (1985) hegðun bandaríska hlutabréfamarkaðsins frá janúar 1926 til desember 1982. Peir mynduðu verðbréfasöfn með hlutabréfum sem skilað höfðu mjög góðri ávöxtun og félögum sem skilað höfðu lélegri ávöxtun. Niðurstaða peirra var að ávöxtun verðbréfasafna sem höfðu skilað góðri sögulegri ávöxtun var mun minni en meðalávöxtun hlutabréfamarkaðsins. Aftur á móti skiluðu verðbréfasöfn sem gerð voru úr félögum sem skilað höfðu lélegri ávöxtun mun betri ávöxtun en markaðurinn að meðaltali. Tölfræðilega marktækur munur var á ávöxtun pessara verðbréfasafna.

Í rannsókn á hlutabréfamörkuðum í Bandaríkjunum, Pýskalandi, Frakklandi, Bretlandi og Japan frá 1985 til 1993 komust Haugen og Baker (1996) að svipuðum niðurstöðum. Niðurstöður peirra voru að sigurvegarar markaðarins, p.e. hlutabréf félaga sem skilað höfðu meiri ávöxtun en meðaltal markaðsins í mánuðinum á undan viðmiðunartímanum, skiluðu lægri ávöxtun en markaðurinn að meðaltali næsta mánuð á eftir viðmiðunartímanum á öllum pessum mörkuðum. Niðurstöður nýlegrar rannsóknar á hlutabréfamarkaðinum í Malasíu frá janúar 1987 til desember 1999 voru hliðstæðar niðurstöðum rannsókna á öðrum mörkuðum. Hlutabréf sigurvegaranna skiluðu slakri ávöxtun en hlutabréf félaga sem skilað höfðu slakri ávöxtun skiluðu mjög góðri ávöxtun par á eftir. Petta átti einkum við um lítil fyrirtæki, en hlutabréf lítilla fyrirtækja sem skilað höfðu slakri ávöxtun skiluðu afburðaávöxtun (Lai o.fl., 2003). 


\subsection{Rannsókn og niðurstöður}

Til að kanna pennan pátt var farin sama leið og hér að ofan hefur verið lýst. Búin voru til fjögur verðbréfasöfn í hverjum mánuði. Í safni 1 eru pau hlutabréf í úrtakinu sem skiluðu lökustu ávöxtuninni í síðasta mánuði á undan viðmiðunartímanum, í safni 2 eru hlutabréfin sem skiluðu næstlökustu ávöxtuninni, síðan kemur safn 3 en í safni 4 eru hlutabréfin sem skiluðu bestri ávöxtun.

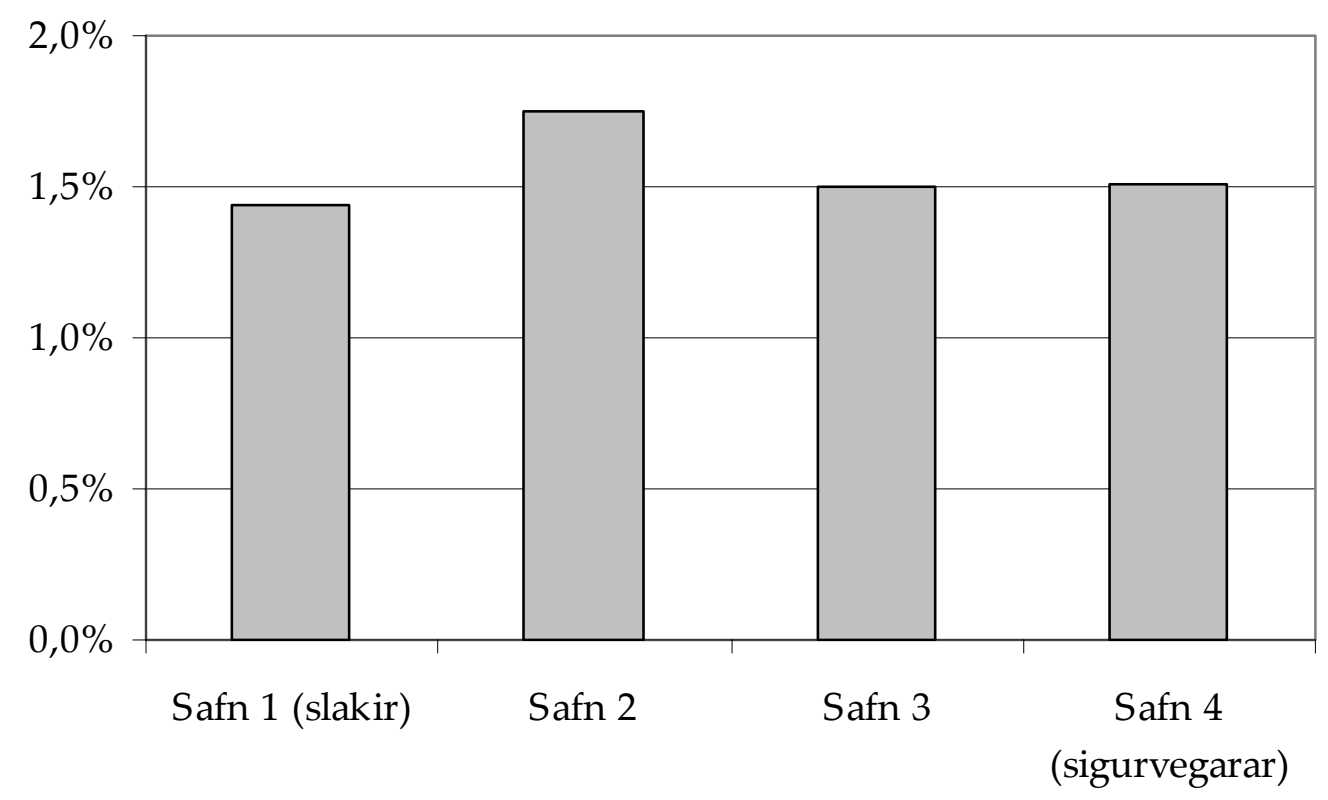

Mynd 7. Meðalávöxtun verðbréfasafna par sem hlutabréfum hafði verið raðað eftir fyrri frammistöðu.

Á mynd 7 sést meðalávöxtun safnanna. Eins og sést á myndinni er ávöxtun allra safnanna svipuð eða nálægt 1,5\% á mánuði að meðaltali. Út frá pessum niðurstöðum er óhætt að fullyrða að ekkert samband hafi verið á milli frammistöðu (ávöxtunar) íslenskra hlutabréfa í hverjum mánuði og ávöxtunar peirra næsta mánuð á undan.

Í töflu 5 eru helstu niðurstöður aðhvarfsgreiningar sýndar. Stuðullinn $d_{L}$ er nálægt pví að vera núll og pví er enginn munur á Jensens $\alpha$-stuðli verðbréfasafna 1 og 4. Pví er hægt að fullyrða að ekkert marktækt samband hafi verið á milli ávöxtunar íslenskra hlutabréfa og ávöxtunar mánaðarins á undan.

Tafla 5. Helstu niðurstöður aðhvarfsgreiningar á verðbréfasöfnum sem raðað er eftir ávöxtun fyrri mánaðar.

\begin{tabular}{lccccc}
\hline & $\alpha_{P}$ & $d_{L}$ & $\beta_{p}$ & $s_{L}$ & $R^{2}$ \\
\hline Stuðull & 0,0051 & $-0,00001$ & 0,87 & $-0,18$ & 0,47 \\
t-gildi & $(1,45)$ & $(-0,02)$ & $\left({ }^{*} 11,56\right)$ & $(-1,48)$ & \\
p-gildi & 0,15 & 0,99 & $<0,0001$ & 0,14 & \\
& & & & & \\
Durbin Watson & 2,06 & & & & \\
* Marktækt miðað við 5\% marktektarkröfu. & & & \\
\hline
\end{tabular}


Pessar niðurstöður hljóta að vekja spurningar. Íslenski hlutabréfamarkaðurinn virðist ekki sýna sams konar hegðun og margir erlendir hlutabréfamarkaðir. Ef einungis er litið til pessara niðurstaðna virðist íslenski markaðurinn vera skilvirkari en margir stórir hlutabréfamarkaðir.

\section{Lokaorð}

Í pessari grein hefur verið rakin viðamikil rannsókn á sambandi ýmissa pátta við ávöxtun á íslenskum hlutabréfum frá ársbyrjun 1993 til loka júní 2003. Kannað var hvort samband hefði verið á milli V/H-hlutfalls, q-hlutfalls, fyrri frammistöðu, stærðar fyrirtækja, arðgreiðslna og ávöxtunar íslenskra hlutabréfa frá ársbyrjun 1993 til loka júní 2003. Pessir pættir voru valdir vegna pess að peir hafa löngum verið í brennidepli við verðmat á hlutabréfamörkuðum. Rannsóknir á erlendum hlutabréfamörkuðum hafa enn fremur sýnt fram á að samband er á milli peirra og ávöxtunar hlutabréfa.

Helstu niðurstöður eru pær að tölfræðilega marktæk tengsl eru á milli V/Hhlutfalls og ávöxtunar. Mest ávöxtun fékkst með pví að velja verðbréfasafn með hlutabréfum í fyrirtækjum með lágt sögulegt $\mathrm{V} / \mathrm{H}$-hlutfall. Jensens $\alpha$-stuðull verðbréfasafnsins með lága $\mathrm{V} / \mathrm{H}$-hlutfallinu var hærri en safnsins með háa $\mathrm{V} / \mathrm{H}$ hlutfallinu með tölfræðilega marktækum hætti. Ávöxtun smærri fyrirtækja og peirra er höfðu lágt q-hlutfall var nokkru meiri en stórra fyrirtækja og peirra er höfðu hátt q-hlutfall en munurinn var hins vegar ekki tölfræðilega marktækur að teknu tilliti til kerfisbundinnar áhættu. Aftur á móti mældist ekkert samband á milli fyrri frammistöðu, sem mæld var eftir ávöxtun í mánuðinum á undan viðmiðunartímanum, og ávöxtun næsta mánaðar á eftir. Enn fremur mældist ekkert samband á milli arðgreiðslna, sem mældar voru eftir arðhlutfalli, og ávöxtunar íslenskra hlutabréfa.

Nú vaknar sú spurning hvor hægt sé að nýta pessar niðurstöður við fjárfestingar. Ljóst er að sú fjárfestingarstefna að kaupa hlutabréf í fyrirtækjum með lágt V/H-hlutfall hefur skilað mun meiri ávöxtun en sú stefna að kaupa hlutabréf í fyrirtækjum með hátt V/H-hlutfall. Meðalávöxtun hlutabréfasafnsins með lægsta V/H-hlutfallið var 2,25\% á mánuði en meðalávöxtun úrvalsvísitölunnar var einungis 1,11\% á sama tíma. Pví er augljóst að fjárfestar gætu með góðum rökum gefið fyrirtækjum með lágt V/H-hlutfall gaum við val á hlutabréfum.

\section{Heimildir}

Árbók 2003. Reykjavík: Kauphöll Íslands. www.icex.is.

Basu, S. (1977). The relationship between earnings, yield, market value and return for NYSE common stocks - further evidence. Journal of Finance, (32), 663-681.

Campbell, J.Y., Lo, A.W. \& MacKinlay, A.C. (1997). The Econometrics of Financial Markets. New Jersey: Princeton University Press. 
Chan, K. \& Lakonishok, J. (2004). Value and growth investing: review and update. Financial Analysts Journal, (60), 71-86.

De Bondt, W. \& Thaler, R. (1985). Does the stock market overreact? Journal of Finance, (40), 793-808.

Elton, E., Gruber, M. \& Rentzler, J. (1983). A simple examination of the empirical relationship between dividend yields and deviations from the CAPM. Journal of Banking and Finance, (7), 135-146.

Fama, E. \& French, K. (1992). The cross-section of expected stock returns. Journal of Finance, (47), 427-465.

Grossman, S. \& Stiglitz, J. (1980). On the impossibility of informationally efficient markets. American Economic Review, (70), 393-408.

Haugen, R.A. \& Baker, N.L. (1996). Commonality in the determinants of expected stock returns. Journal of Financial Economics, (41), 401-439.

Jensen, M. (1968). The performance of mutal funds in the period 1945-1964. Journal of Finance, (23), 389-416.

Jahnke, G., Klaffke, S.J. \& Oppenheimer, H.R. (1987). Price-earnings ratios and security performance. Journal of Portfolio Management, (14), 39-46.

Lai, M., Guru, B. \& Nor, F. (2003). Do Malaysian investors overreact? Journal of American Academy of Business, (2), 602-609.

Levis, M. (1989). Stock market anomalies: a reassessment based on UK evidence. Journal of Banking and Finance, (13), 675-696.

Lintner, J. (1965). The Valuation of Risky Assets and the Selection of Risky Investments in Stock Portfolios and Capital Budgets. Review of Economics and Statistics, (47), 13-37.

Lofthouse, S. (1994). Equity investment management - how to select stocks and markets. New York: John Wiley.

Markowitz, H. (1959). Portfolio Selection: Efficient Diversification of Investments. New York: John Wiley.

Resenburg, P. \& Rousseau, R. (2004). Time and the payoff to value investing. Journal of Asset Management, (4), 318-325.

Sharpe, W. (1964). Capital Asset Prices: A Theory of Market Equilibrium under Conditions of Risk. Journal of Finance, (19), 425-442. 